\title{
Hypermutated Sample
}

National Cancer Institute

\section{Source}

National Cancer Institute. Hypermutated Sample. NCI Thesaurus. Code C162258.

A molecular finding indicating that the mutation rate is higher than 10 mutations per megabase (Mb) in a tissue sample. 